Mr. Carnegie in rgor gave a million pounds to provide funds " for improving and extending the opportunities for scientific study and research in the Universities of Scotland, my native land," to quote from his trust deed. ' In the University of Aberdeen, of which I have the honour to be a member, out of $\mathrm{I}_{32}, 000 l$. allocated from this benefaction in the period of $15^{\frac{3}{4}}$ years, a bare one-quarter has gone to science; 52,1187 . has gone to endow one professorship in history and five lectureships in French, political economy, German, education, and constitutional law and history; $24,750 l$. has been assigned to provide new buildings for teaching arts subjects, a new examination hall, and an extension of the library; $26,75 \mathrm{ol}$. has gone, $\mathrm{x}_{5}, 75 \mathrm{ol}$. to maintenance of the library and in,oool. for provisional assistance in teaching, science being represented in this to an indefinite extent. The remaining $28,382 l$. has gone to science, I5,75ol. for the equipment of laboratories, and $12,632 l$. as an endowment for a lectureship in geology. With reference to the latter, the Geological Department, taking the figures for the year before the war, was entirely supported by the fees paid by the students, and geology got the interest of the $12,632 l$. in the same sense as the PostmasterGeneral gets the sovereign when you purchase a $20 s$. postal order. Personally I think calling science what is not science needs to be watched and checkmated.

University of Aberdeen, September 30 . Frederick SoDdy.

\section{AN IMPERIAL DEPARTMENT OF MINERAL PRODUCTION.}

THE presidents of the technical institutes most closely connected with the production and utilisation of our mineral resources have addressed to the Advisory Council for Scientific Research a memorandum advocating the establishment of a central Government Department, the duty of which should be to foster the development of the mineral resources of the British Empire. Whatever form such a department may take, the need for its creation is very obvious. In Great Britain no such department exists. The Geological Survey, under the Board of Education, records the existence of mineral deposits, but always from the point of view of the geologist, whose main interest lies in their mode of occurrence and not in their exploitation. The Inspectorate of Mines under the Home Office is concerned only with the due policing of mines from the point of view of safety; its ideal would be a state of affairs in which mining accidents were reduced to zero; and even though this were brought about by the cessation of all mining, the Inspectorate of Mines would have fulfilled the object for which it exists. The Board of Trade, the Imperial Institute, and many other departments of the Government take a more or less desultory interest in mineral production, but there is no one department the special duty, of which it is to watch over the development and proper utilisation of our mineral resources.

What is needed is a Ministry of Production, or something equivalent thereto, which should have for its particular object the care of developing all the natural resources of the Empire. All natural products may be divided into three groups: they are produced by the cultivator, by the hunter or fisherman, or by the miner. Of all these the last-named needs the most careful attention, because minerals alone constitute a wasting asset; unlike the other products, they are not renewed, and, once exhausted, are gone for ever. The cultivation of a field on wrong principles will entail losses for a year or two, but these are quite remediable, and the application of proper methods will restore it to fruitfulness; but a mine worked on wrong principles is ruined for ever, and mineral not properly wrought is in the vast majority of cases lost irrecoverably.

It is this consideration that renders the need for a Ministry or Department devoted to the administration of our mineral resources so very urgent. In most Continental countries the minerals have remained the property of the State, and the State has therefore a direct pecuniary interest in seeing to their development as an integral part of the national revenue. In this country and in America the State has found it advantageous to relinquish the State ownership of minerals, it being held that the development of the national mineral resources is thus facilitated, and that such free development is of more benefit to the nation than the revenue which might be derived from its mineral concessions. As regards purely fiscal reasons, these two nations are accordingly not directly concerned in the development of their mineral wealth, but it by no means follows that they should treat the subject with indifference. In the United States there is a Department of Mines that takes a very active interest in encouraging the mineral output. In Canada there is a Department of Mines upon somewhat similar lines, which is doing excellent work, and under the fostering care of which the mineral output of Canada is making rapid advances.

There was a time when Great Britain stood at the head of all nations as a mineral producer, at any rate as regards a considerable number of important minerals and metals; that we have fallen far behind to-day is due no doubt in great measure to natural causes, but their effect has been and is being accelerated by the fact that it has been nobody's business to see to it that our mineral resources were worked to best advantage; whenever legislation has touched mining, it has been to hinder, not to help, mining operations, mainly because there was no great Department of State to look after our mineral interests. Wastefulness in the production and utilisation of our mineral resources has gone on and is going on unheeded and unchecked, mainly again for the same reason. The need for a State Department administered on sound economic lines, as free from political bias as our national methods admit of, is perhaps more urgent for the British Isles in the first instance, but together with this and above this, there should be an organisation for protecting the mineral industries of our whole world-wide Empire, for consolidating the resources of the Empire, and for rendering it impossible that in the future the control of any portion of the Empire's mineral production should ever pass into alien hands.
HeNRY Louis.

No. 2449, VOL. 98] 